hydrogen in presence of a catalyst, at various temperatures and pressures, now contribute about 65 per cent. of the world's supply of fixed nitrogen. In this process the cost of producing and purifying the hydrogen is a dominating factor; in Germany it is prepared from water-gas (Bosch process), in France by fractionating coke-oven gas (Claude process), and in Italy by electrolysing water (Casale and Fausser processes). Electrolytic hydrogen is very pure, but its production is only feasible where water-power is cheap. The Casale process is being actively worked in Calabria by a company with a capital of 9 million Swiss francs, and in the United States the Hooker Chemical Co. is so satisfied with its success that it has decided to double its plant at Niagara Falls.

Other important factors in the Haber process are the choice of catalysts and the form of marketing the ammonia. In the Fixed-Nitrogen Research Laboratory of the United States Government, improved catalysts have been made which, it is expected, will reduce the cost of ammonia-production by one-half ; working on a small scale, at 1500 atmospheres pressure, nearly 80 per cent. of a nitrogen-hydrogen mixture was converted during a single passage through the catalyst. Improved catalysts have also been made for the watergas reaction $\left(\mathrm{CO}+\mathrm{H}_{2} \mathrm{O}=\mathrm{H}_{2}+\mathrm{CO}_{2}\right)$. With these and other improvements it is hoped to reduce the price of ammonia to 5-6 cents per $\mathrm{lb}$.

At Billingham-on-Tees, Synthetic Ammonia and Nitrates, Ltd., has started manufacture on a large scale A modified Haber process is used, and the ammonia is fixed by the calcium-sulphate method, which was developed, and is still used, in Germany. It is probable that synthetic ammonia will be used in conjunction with the Solvay soda process, the ammonia being converted into ammonium chloride, which preliminary trials have shown to be comparable with ammonium sulphate in fertilising value.

The Bucher process of fixing nitrogen as cyanide has not fulfilled expectations, but it appears probable that the du Pont Co. will make it a success. Instead of passing nitrogen (at ${ }_{5} \mathrm{lb}$. pressure) over soda ash, coke, and a catalyst, this company uses producer-gas and a mixture of carbon black and soda ash (plus catalyst) obtained by evaporating to dryness the "blatk liquor". which results from boiling wood with caustic soda in the manufacture of wood-pulp, and by heating the residue out of air at $250^{\circ}-35^{\circ} \mathrm{C}$. This mass is very porous, and contains $60-65$ per cent. soda ash and $40-35$ per cent. carbon, mainly colloidal. The yield of cyanide at this stage is $5^{0-55}$ per cent., and the period of heating is only 70 per cent. of that required in the original process. The reaction-product is leached with water, and 96-98 per cent. sodium cyanide is obtained by crystallisation. The carbon monoxide evolved during heating is mixed with producer-gas and burned under the retorts, which are made of very resistant cast. chrome-iron alloy, high in chromium. A valuable decolorising carbon is extracted from the residue after leaching. Cyanide, it may be mentioned, can be decomposed by steam to yield ammonia.

The marvellous growth of the nitrogen-fixation industry has naturally excited those interested in the production of Chilean nitrate, the consumption of which has not advanced pari passu with that of the artificial products; but the processes used in Chile are known to be wasteful, the Chilean Government could reduce the export tax of 50 s. per ton in case of emergency, and the deposits are likely to last much longer than was originally thought probable. In view, however, of the fact that no other nitrate deposits, in any way comparable with those of Chile, have been dis covered, it can only be a question of time-a generation or two-before the synthetic products will hold undisputed sway. It is, of course, possible that means may be found of speeding up nitrification in the soil but even in that event no nation could afford to be without a nitrogen industry for producing explosives. Furthermore, fixed nitrogen is being increasingly used as ammonia for cold-storage plants, as cyanide for gold extraction, and as nitro-cellulose for making celluloid, artificial leather, and similar products. Great developments of the industry may, therefore, be confidently. anticipated.

\title{
Obituary.
}

\section{The Marquess Curzon of Kedleston, K.G., F.R.S.}

$\mathrm{BY}$ the death of Lord Curzon, Lord President of the Council, and formerly Viceroy of India and Secretary of State for Foreign Affairs, on March 2o, public life in Great Britain has lost one of its most striking personalities. His long and distinguished career in politics had won him high honours in the State; but in a more restricted circle he was held in equal esteem for his scholarship and his efforts to promote those studies with which his interests and pursuits had brought him into touch.

George Nathaniel Curzon, son of Lord Scarsdale, was born on January $x 1,1859$. After a distinguished career at Eton and Oxford, which included the presidential chair of the union and led to a fellowship of All Souls, Mr. Curzon, as he then was, embarked on a political career, entering Parliament in 1887 , first holding office as Under-Secretary of State for India in I891, by which time he was already recognised as an authority on the East. It is unnecessary to enter here into the details of his political career, which are well known. His services to the State were recognised by successive peerages of every grade up to the rank of marquess and the orders of the Garter, the Indian Empire, the Star of India, and the Royal Victorian Order.

Apart from politics, Lord Curzon won distinction as a geographer and student of the peoples of the East. Between 1886 and 1894 he visited India four times and twice travelled round the world. In I 888 he travelled through Asiatic Russia, recording his observations in his book "Russia in Central Asia." He followed this with a book on Persia and the Persians, a comprehensive account and perhaps his most considerable contribution to geographical literature, which later was to have considerable effect on policy in the Middle East and is still a work of authority. This appeared after a journey in Persia as correspondent of the Times in 1889 , in the course of which he travelled more than r6oo miles on horseback and toured the Persian Gulf. A later book, "Problems of the Far East," dealt with conditions in and the prospects of the countries lying 
between India and the Pacific. In 1894 he visited the Ameer of Afghanistan-then an undertaking entailing some considerable risk-after tracing the Oxus to its source in the Pamirs. Behind his preoccupation with races and people as factors in international politics, Lord Curzon had a fund of sound geographical knowledge, and in fact, as was shown by essays in his often amusing "Stories of Travel," published in I923, he was a scientific geographer of no small attainment. In geography and in the study of peoples, as in his work as an administrator, it was characteristic of him to pursue exhaustive inquiry and to master the available data relating to his subject before arriving at any conclusion on his own observations. The result would then be expressed with a lucidity which reflected his clarity of judgment. His contributions to geographical science were recognised in $\mathrm{I} 895$ by the award of the Royal Geographical Society's gold medal, an honour which he prized highly.

As Viceroy of India Lord Curzon did much to promote science in that country. Apart from his lasting reforms in education and his efforts to improve the conditions of agriculture, both being placed under trained officers, he reorganised the archæological service, which had fallen into neglect, reviving the office of Director-General. In 1904 he passed a Monuments Act, and he saved from profanation and decay innumerable temples, tombs of kings, mosques, and other buildings throughout India, including the native states. Native arts and industries were fostered, and he created the Imperial Library in the Metcalfe Hall and was responsible for the Victoria Memorial on the Maidan, Calcutta, a gallery of Indian art and history. His own researches into the history of his predecessors in the Viceregal office were on the point of publication at the time of his death.

It may be recalled that Lord Curzon and Lord Kitchener were the principal guests of the Royal Society at its anniversary dinner in 1898 . Within a few days both were due to leave England to take up their new Indian appointments. In a letter to Lord Lister, the president, a few days prior to the banquet, Lord Curzon wrote: "It is the instinct of the hunted animal to fly, but your invitation to me has been expressed so gracefully that I cannot but accept." Lord Curzon made an interesting speech at the dinner, referring, among other matters, to a Viceroy's horoscope. An outgoing Viceroy, he said, is fêted and dined and toasted before he has gone out to his work, and, indeed, before he has done anything at all. Five years later, upon his return, he slips back into Great Britain almost unperceived, and retires, very likely, into an obscurity which may or may not be merited, but is, at any rate, in striking contrast to the plaudits which attended his departure. Happily, in Lord Curzon's case, such prophecy was unfulfilled.

Lord Curzon's interest in the relics of antiquity were not confined to India. It was through his efforts that Tattershall Castle, Lincolnshire, was saved for the nation when about to be demolished, and through him the castles at Bodiam in Sussex, and Montacute in Somerset, were also preserved.

Lord Curzon was the recipient of many honours bestowed by the learned and scientific world. He was president of the Royal Geographical Society from I9I I until I9I4. He was elected Chancellor of the University of Oxford in 1907, when he took a prominent part in the movement for " reform from within." $\mathrm{He}$ was Lord Rector of the University of Glasgow in 1908 , Romanes Lecturer at Oxford in 1907 , and Reed Lecturer at Cambridge in I9I3. He was an honorary fellow of Balliol, and held honorary degrees from the Universities of Oxford, Cambridge, Glasgow, and Manchester. He was a fellow of the Royal Society and British Academy, and had accepted the presidency of the English Association not very long before his death.

\section{Lord Curzon in INDIA.}

EXCEPT in so far as it had a direct influence on economic development or on humanitarian problems, Lord Curzon, during his Indian Viceroyalty, showed no marked interest in scientific research. Science did not appeal to him as a branch of culture comparable to history and literature. It is true that, four years before he was appointed Viceroy, he had made a distinct mark as an explorer in the Pamirs, when he solved the problem of the source of the Oxus; but this diversion to physical geography was rather an accidental byproduct in a journey mainly devoted to the political aspects of geography and sport. Still, the recognition of this work by the Royal Geographical Society left him with the impression that geography at any rate was a science, and, so far as one could guess from his official and personal activities in India, it gave him the impression also that science was geography. Workers in other branches he seemed to regard as having a limited usefulness in solving political and economic problems, and sometimes in assisting his remarkable work in restoring respect for India's unappreciated relics of archæological and historical value. His action in dispersing the fine collection of fishes (which had been prepared by Col. Alcock in the Calcutta Museum), to provide an opportunity for a preliminary display of the historical collections designed for the Victoria Memorial, revealed his want of appreciation of the claims of those forms of culture that had had no part in his earlier education. Fortunately, no other science workers offered obstacles to his activities, and so they could not share to the full the resentment displayed by the zoologists.

Nevertheless, when Lord Curzon realised that science was necessary for economic progress, he recognised the value of laying sound foundations in research which could offer no prospect of definite results in his own time. In this matter he was fortunate in having as members of his Government two Ministers--Sir Denzil Ibbetson and Sir John Hewett-who realised that the development of pure science was essential to solid advancement in its application. Lord Curzon's institution of the Imperial Agricultural Department, by recruiting into one service a strong staff of chemists, botanists, plant pathologists, entomologists, and other specialists devoted to agricultural problems, has already brought to the Indian cultivator direct returns in increased output annually, many times more than the total cost of the new service from its start.

Although most science workers in India during the years 1898 to 1905 remained outside the Viceroy's wide range of active interests, the wiser among them realised that their position was not without some advantages ; his zeal for reform was dominated always by a desire for centralised control and symmetry in system of administration-conditions which may have conduced 